Jurdimas (Jurnal Pengabdian Kepada Masyarakat) Royal

Vol. 4 No. 2, Mei 2021, hlm. 121 - 126

ISSN 2614-7912 (Print)

DOI: https://doi.org/10.33330/jurdimas.v4i2.928

ISSN 2622-3813 (Online)

Available online at https://jurnal.stmikroyal.ac.id/index.php/jurdimas

\title{
PELATIHAN PEMBUATAN PRODUK TEH BERBAHAN DASAR JAGUNG SEBAGAI ANTIOKSIDAN KEPADA MASYARAKAT
}

\author{
Miftahul Khair Kadim ${ }^{1}$, Nuralim Pasisingi ${ }^{1 *}$, Wila Rumina Nento ${ }^{2}$ \\ ${ }^{1}$ Manajemen Sumberdaya Perairan, Universitas Negeri Gorontalo \\ ${ }^{2}$ Teknologi Hasil Perikanan, Universitas Negeri Gorontalo \\ email:*nuralim@ung.ac.id
}

\begin{abstract}
North Gorontalo has considerable potential, especially in the agricultural sector. One of the excellent agricultural sectors is the corn crop. Although corn is a popular commodity in North Gorontalo District, the utilization and diversification of its processed products is still low. Corn hair contains antioxidants, one of which can be developed into tea products. This activity aims to improve the skills of local communities in processing corn into antioxidant tea products. The community service activities were carried out in Bualo Village, Biau District, North Gorontalo for 45 days, starting from September 3 to October 18, 2020. The training was carried out by providing education about the use of corn as a basic ingredient for processing and continued with practical activities for making ready-to-brew antioxidant tea. The result of this training activity was an increase in the knowledge of the local community in Bualo Village about the use of corn as a basic material for processing antioxidant tea products along with attractive packaging.
\end{abstract}

Keywords: antioxidant; bualo; tea

\begin{abstract}
Abstrak: Gorontalo Utara memiliki potensi yang cukup besar terutama pada sektor pertanian. Salah satu sektor pertanian yang menjadi primadona adalah tanaman jagung Meskipun jagung merupakan komoditi populer di kabupaten Gorontalo Utara, pemanfaatan dan diversifikasi produk olahnnya masih tergolong rendah. Rambut jagung mengandung antioksidan yang salah satunya dapat dikembangkan menjadi produk teh. Kegiatan ini bertujuan untuk meningkatkan keterampilan masyarakat lokal dalam mengolah jagung menjadi produk teh antioksidan. Kegiatan pengabdian dilaksanakan di desa Bualo, Kecamatan Biau, Gorontalo Utara selama 45 hari, mulai dari tanggal 3 September hingga 18 Oktober 2020. Pelatihan dilakukan dengan memberikan edukasi tentang pemanfaatan jagung sebagai bahan dasar pengolahan dan dilanjutkan dengan kegiatan praktik pembuatan teh antioksidan siap seduh. Masyarakat Desa Bualo telah memiliki keterampilan tambahan dalam membuat produk teh antioksidan dengan kemasan yang menarik sebagai produk inovasi dalam rangka meningkatkan perekonomian masyarakat lokal.
\end{abstract}

Kata kunci: antioksidan; bualo; teh 
Jurdimas (Jurnal Pengabdian Kepada Masyarakat) Royal

Vol. 4 No. 2, Mei 2021, hlm. 121 - 126

ISSN 2614-7912 (Print)

DOI: https://doi.org/10.33330/jurdimas.v4i2.928

ISSN 2622-3813 (Online)

Available online at https://jurnal.stmikroyal.ac.id/index.php/jurdimas

\section{PENDAHULUAN}

Indonesia merupakan negara dengan kekayan alam melimpah yang memiliki potensi sangat besar di sektor pertanian. Sektor pertanian memiliki peran penting dalam pembangunan Indonesia, hal ini dapat dilihat dari kontribusi sektor pertanian terhadap perekonomian nasional. Salah satu tanaman palawija yang banyak dibudidayakan oleh petani di Indonesia adalah tanaman jagung (Remedy, 2015).

Wilayah kabupaten Gorontalo Utara memiliki potensi yang cukup besar terutama pada sektor pertanian. Sektor pertanian menjadi sumber pemasukan terbesar bagi pendapatan provinsi Gorontalo. Salah satu sektor pertanian yang menjadi primadona adalah tanaman jagung sehingga provinsi Gorontalo menjadi salah satu provinsi yang memiliki peran penting dalam produksi jagung nasional.

Jagung merupakan komoditi unggulan di kabupaten Gorontalo Utara. Menurut data Badan Pusat Statistik kabupaten Gorontalo Utara (BPSK Gorut) tahun 2015, luas panen jagung pada tahun 2015 mencapai 9.054 ha, rata-rata tingkat produksitivitas sebesar 44,30 kwintal/ha, maka produksi jagung diperkirakan mencapai 40.108 ton jagung pipilan kering. Secara psikologis keberadaan komoditas jagung bagi masyarakat diseluruh wilayah Gorontalo, merupakan satu sisi penting yang hampir tidak bisa dilepaskan dari potret kehidupan masyarakat perdesaan. Secara tradisional, sejak dulu jagung juga telah dijadikan sebagai makanan pokok masyarakat Gorontalo (Anugrah, 2016).

Pandemi Covid-19 yang melanda dunia saat ini tidak terkecuali Indonesia mengharuskan manusia memiliki imunitas tubuh yang baik agar tidak mudah terjangkit virus ini. Manusia membutuhkan senyawa antioksidan dan itu dapat diperoleh dari makanan (Pietta, 2000). Jagung mengandung precursor vitamin $\mathrm{A}$ atau karotenoid dan vitamin $\mathrm{E}$ yang memiliki fungsi sebagai zat gizi mikro (Suarni \& Widowati, 2017), vitamin tersebut berperan sebagai antioksidan alami yang dapat meningkatkan imunitas tubuh dan menghambat kerusakan degeneratif sel.

Antioksidan didifinisikan sebagai inhibitor yang bekerja menghambat oksidasi dengan cara bereaksi dengan radikal bebas reaktif membentuk radikal bebas tak reaktif yang stabil (Zheng \& Wang, 2001). Antioksidan adalah zat yang dapat menunda, memperlambat dan mencegah terjadinya proses oksidasi atau menetralisir radikal bebas (Fajriah, Darmawan, Sundowo, \& Artanti, 2007). Antioksidan sangat bermanfaat bagi kesehatan karena sangat potensial dalam mencegah kanker, menambah daya tubuh dan sebagai anti virus (Gross \& Budowski, 1966).

Penelitian terkait pengolahan jagung yang diterapkan dalam masyarakat telah banyak dilakukan dintaranya yang telah dilaporkan oleh (Purnomo, Sitanggang, Agustin, Hariyadi, \& Hartono, 2012); (Aprilliani, Bano, \& Levis, 2019); (Kurniasih \& Dewi, 2019); (Kresnatita \& Oemar, 2020). Rambut jagung mengandung senyawa bioaktif seperti flavonoid dan saponin yang merupakan senyawa metabolit sekunder yang berpotensi sebagai antioksidan. Rambut jagung adalah bagian jagung yang umumnya dibuang karena tidak dimanfaatkan dan dikonsumsi manusia. Teh antioksidan berbahan dasar rambut jagung sebagai produk lokal desa setempat sangat potensial untuk dikembangkan menjadi produk inovasi dalam rangka meningkatkan 
Jurdimas (Jurnal Pengabdian Kepada Masyarakat) Royal

Vol. 4 No. 2, Mei 2021, hlm. 121 - 126

ISSN 2614-7912 (Print)

DOI: https://doi.org/10.33330/jurdimas.v4i2.928

ISSN 2622-3813 (Online)

Available online at https://jurnal.stmikroyal.ac.id/index.php/jurdimas

perekonomian lokal.

\section{METODE}

Kegiatan pengabdian ini dilaksanakan di desa Bualo, Kecamatan Biau, Gorontalo Utara selama 45 hari, mulai dari tanggal 3 September hingga 18 Oktober 2020. Sasaran dari kegiatan ini adalah ibu-ibu PKK yang terbagi menjadi 3 kelompok, masing-masing kelompok terdiri dari 10 orang anggota. Selain itu kegiatan ini juga melibatkan 30 orang mahasiswa dari Universitas Negeri Gorontalo yang bertugas sebagai pendamping kelompok masyarakat. Metode pelaksanaan kegiatan dilakukan dalam bentuk pelatihan dan praktik partisifatif.

Adapun Tahapan dalam kegiatan dibagi menjadi tiga tahapan yaitu tahap persiapan dimana tim pengambdian melakukan survei lapangan untuk mengetahui permasalahan yang dihadapai mitra maka tim menyepakati untuk memberikan pengetahuan baru tentang manfaat rambut jagung. Tahap ke dua yaitu Pelatihan pembuatan teh berbahan dasar rambut jagung dilaksanakan pada tanggal 15 September 2020.

Pelatihan dilakukan dengan memberikan edukasi tentang pemanfaatan jagung sebagai bahan dasar pengolahan teh herbal, memberikan informasi tambahan tentang manfaat tanaman jagung yang dapat diolah seluruhnya untuk berbagai kepentingan masyarakat di desa Bualo, dan dilanjutkan dengan tahap ketiga yaitu kegiatan praktik pembuatan teh antioksidan berbahan dasar rambut jagung, yang nantinya pada kegiatan ini masyarakat mendapatkan bekal aplikatif dalam memafaatkan dan mengolah jagung menjadi produk lain.

\section{PEMBAHASAN}

\section{Edukasi Pemanfaatan dan Pengolahan Jagung.}

Kegiatan ini bertujuan untuk memberikan pemahaman tambahan kepada masyarakat tentang manfaat jagung. Seperti yang diketahui bahwa kabupaten Gorontalo Utara merupakan salah satu kabupaten penghasil jagung terbesar di provinsi Gorontalo. Paradigma yang berkembang di masyarakat desa khususnya di desa Bualo bahwa jagung hanya bisa dimanfaatkan sebagai alternatif pengganti beras, dimana pemanfaatannya masih secara tradisonal (buah jagung cukup di rebus dan dimakan).

Pelatihan ini memberikan informasi tambahan tentang manfaat tanaman jagung yang dapat diolah seluruhnya untuk berbagai kepentingan masyarakat di desa Bualo, mulai dari edukasi memanfaatkan buah jagung hingga bagian yang dianggap tidak bermanfaat dan menjadi limbah, seperti bagian rambut, tongkol hingga batang tanaman jagung. Hal ini kedepannya diharapkan dapat membantu mengurangi permasalahan yang diakibatkan oleh limbah tanaman jagung. Materi edukasi yang diberikan pada saat pelatihan berupa bagaimana cara memanfaatkan rambut dari jagung menjadi teh yang memiliki manfaat karena mengandung antioksidan yang sangat bermanfaat terutama di masa pandemi Covid-19, materi tentang memanfaatkan buah jagung menjadi produk es krim dan materi tentang bagaimana cara memanfaatkan limbah batang tanaman jagung sebagai pakan ternak.

Pelatihan ini berhasil mengedukasi dan merubah paradigma masyarakat tentang jagung itu sendiri. Respon baik dari masyarakat dan aparat desa menghasilkan antusias dan 
Available online at https://jurnal.stmikroyal.ac.id/index.php/jurdimas

menurunkan pesimisme masyarakat seiring dengan berjalannya kegiatan edukasi.

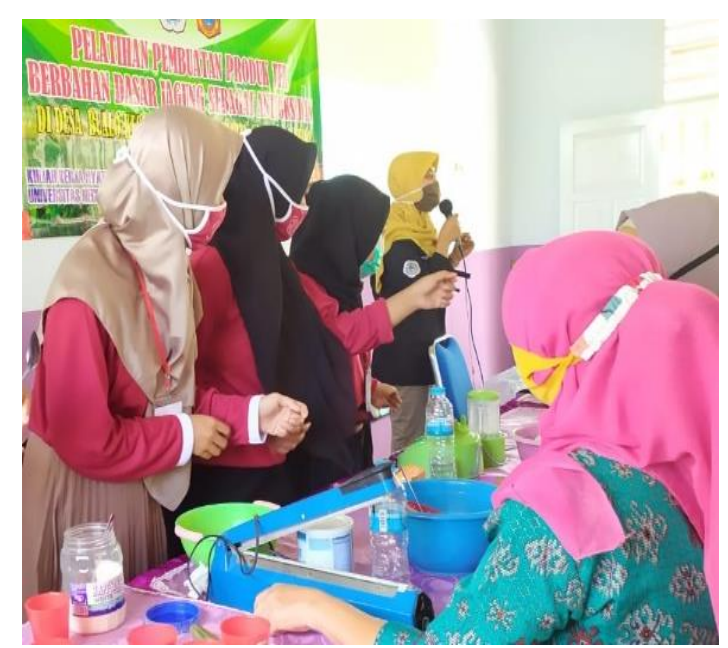

Gambar 1. Edukasi Pemanfaatan dan Pengolahan Jagung.

\section{Kegiatan Praktik Pembuatan Produk Teh Antioksidan}

Selain edukasi melalui pemberian teori, masyarakat juga diajak untuk melakukan praktik pengolahan. Kegiatan praktik ini merupakan bagian dari transfer pengetahuan yang dilakukan dalam kegiatan pengabdian ini.

Melalui kegiatan ini masyarakat mendapatkan bekal aplikatif dalam memafaatkan dan mengolah jagung menjadi produk lain. Bagian jagung yang dimanfaatkan dalam praktik pembuatan teh ini adalah bagian rambut. Masyarakat dibimbing dan diarahkan mulai dari tahap menyiapkan alat dan bahan, mengolah rambut jagung dengan cara yang higienis hingga menjadi produk teh (Gambar 2).

Selanjutnya masyarakat juga dibimbing tentang cara mendesain kemasan hingga proses pengemasan agar produk teh tersebut dapat terlihat menarik dan bernilai jual. Produk teh rambut jagung ini dikemas sedemikian rupa agar bisa langsung dikonsumsi dengan cara diseduh dengan air panas tanpa harus menyisakan ampas, adapun produk teh yang telah di kemas dapat dilihat pada gambar 3 .

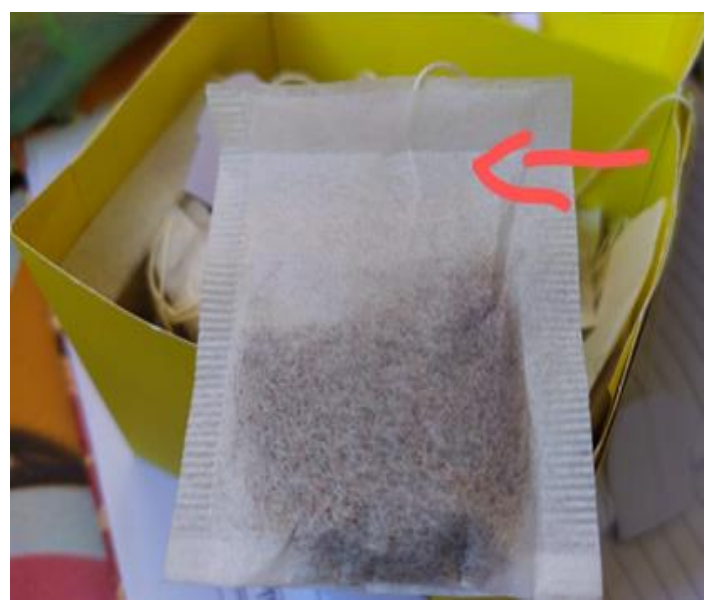

Gambar 2. Produk Teh

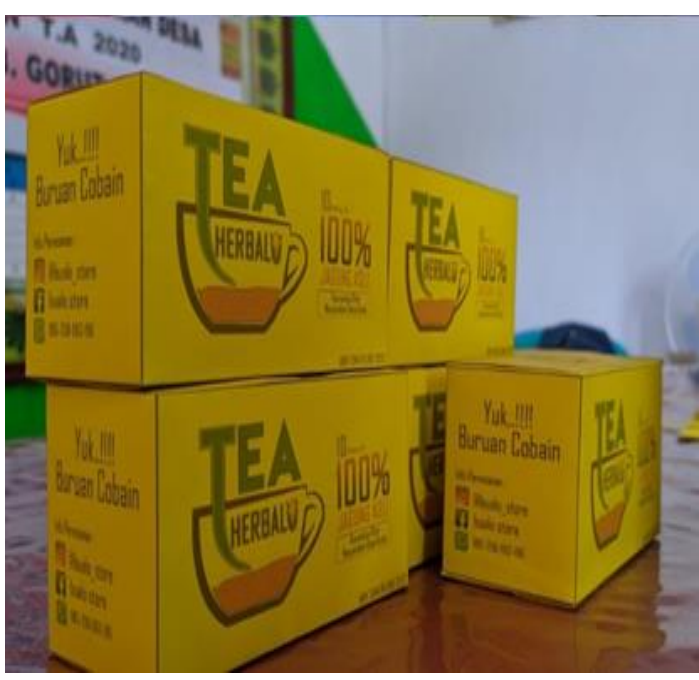

Gambar 3. Produk Teh yang sudah di Kemas

Respon baik datang dari peserta yang begitu antusias mengikuti kegiatan praktik ini. Aparat Desa melalui Kepala Desa juga akhirnya berinisiatif memasukkan produk teh antioksidan ini menjadi produk unggulan Desa yang nantinya diharapkan dapat meningkatkan ekonomi masyarakat. 
Jurdimas (Jurnal Pengabdian Kepada Masyarakat) Royal

Vol. 4 No. 2, Mei 2021, hlm. 121 - 126

ISSN 2614-7912 (Print)

DOI: https://doi.org/10.33330/jurdimas.v4i2.928

ISSN 2622-3813 (Online)

Available online at https://jurnal.stmikroyal.ac.id/index.php/jurdimas

\section{SIMPULAN}

Dari hasil kegiatan pelatihan dan edukasi yang telah dilakukan Tim pengabdian, masyarakat desa Bualo dapat membuat sebuah produk teh antioksi yang berbahan dasar dari rambun jagung. Dapat disimpulkan masyarakat desa Bualo telah memiliki keterampilan tambahan dalam membuat produk teh antioksidan dengan kemasan yang menarik sebagai produk inovasi dalam rangka meningkatkan perekonomian masyarakat lokal. Serta menambah peningkatan pengetahuan masyarakat tentang pemanfaatan jagung sebagai bahan dasar pengolahan produk makanan/minumam.

\section{UCAPAN TERIMA KASIH}

Penulis mengucapkan terima kasih kepada LPPM Universitas Negeri Gorontalo atas bantuan, dukungan dan kerjasamanya sehingga kegiatan ini dapat terlaksana dengan baik. Tak lupa pula rasa terima kasih kami sampaikan kepada Perangkat Desa Bualo yang telah banyak membantu dan memfasilitasi penulis selama kegiatan pengabdian berlangsung.

\section{DAFTAR PUSTAKA}

Anugrah, I. S. (2016). Pembangunan Perekonomian Perdesaan berbasis Agribisnis Jagung di Provinsi Gorontalo. Pembangunan Perekonomian Perdesaan Berbasis Agribisnis Jagung Di Provinsi Gorontalo, 8(4), 363383. Retrieved from https://doi.org/10.21082/akp.v8n4 .2010.363-383

Aprilliani, A., Bano, M., \& Levis, L. R. (2019). Analisis Nilai Tambah
Diversifikasi Produk Olahan Jagung. Exellentia, 8(2), 115-123.

BPSK Gorut. (2015). Kabupaten Gorontalo Utara dalam Angka 2015. Retrieved from Gorontalo:

Fajriah, S., Darmawan, A., Sundowo, A., \& Artanti, N. (2007). Isolasi senyawa antioksidan dari ekstrak etil asetat daun benalu (Dendrophthoe pentandra L. Miq) yang tumbuh pada inang lobi-lobi. Jurnal Kimia Indonesia, 2(1), 1720.

Gross, J., \& Budowski, P. (1966). Conversion of carotenoids into vitamins A1 and A2 in two species of freshwater fish. Biochemical Journal, 101, 747754. Retrieved from https://doi.org/10.1042/bj1010747

Kresnatita, S., \& Oemar, O. (2020). Pelatihan Diversifikasi Produk Olahan Jagung Manis Di Kelurahan Kalampangan Kota Palangka Raya. Jurnal Pengabdian Kampus, 7(1), 23-29.

Kurniasih, Y., \& Dewi, C. A. (2019). Pemberdayaan Petani Jagung melalui Pengembangan Usaha Diversifikasi Produk Olahan Jagung di Labuapi Kabupaten Lombok Barat. Buletin Udayana Mengabdi, 18(3), 43-48. Retrieved from https://doi.org/10.24843/bum.201 9.v18.i03.p08

Pietta, P. G. (2000). Flavonoids as antioxidants. Journal of Natural Products, 63(7), 1035-1042. Retrieved from https://doi.org/10.1021/np990450 9

Purnomo, E. ., Sitanggang, A. B., Agustin, D. S., Hariyadi, P., \& Hartono, S. (2012). Formulation and Process Optimization of 
Jurdimas (Jurnal Pengabdian Kepada Masyarakat) Royal

Vol. 4 No. 2, Mei 2021, hlm. 121 - 126

ISSN 2614-7912 (Print)

DOI: https://doi.org/10.33330/jurdimas.v4i2.928

ISSN 2622-3813 (Online)

Available online at https://jurnal.stmikroyal.ac.id/index.php/jurdimas

Muffin Produced From

Composite Flour of Corn, Wheat and Sweet Potato. Jurnal Teknologi Dan Industri Pangan, 23(2), 165-172. Retrieved from https://doi.org/10.6066/jtip.2012.2 3.2.165

Remedy, T. (2015). Analisis FaktorFaktor yang Mempengaruhi Produksi Jagung (Studi Kasus di Kecamatan Mranggen Kabupaten
Demak).

Suarni, \& Widowati, S. (2017). Struktur, komposisi, dan nutrisi jagung. Puslitbang Tanaman Pangan.

Zheng, W., \& Wang, S. Y. (2001). Antioxidant activity and phenolic compounds in selected herbs. Journal of Agricultural and Food Chemistry, 49(11), 5165-5170. Retrieved from https://doi.org/10.1021/jf010697n 